\title{
Bullying Behavior and Social Interaction Ability of School-age Children in Tambangan Public Elementary School 02 Mijen Semarang
}

\author{
Tri Sakti Widyaningsih ${ }^{\text {1)(corresponding author), Rizki Amalia }}{ }^{2)}$, Tamrin ${ }^{3)}$ \\ ${ }^{1)}$ Departement of Nursing, STIKes Widya Husada Semarang, Indonesia; imoet.sakti@ gmail.com \\ ${ }^{2)}$ Departement of Nursing, STIKes Widya Husada Semarang, Indonesia; rizkiamaliaa0712@ gmail.com \\ ${ }^{3)}$ Departement of Nursing, STIKes Widya Husada Semarang, Indonesia; ns.tamrin86@gmail.com
}

Submitted: September 5, 2019 -Revised: October 10, 2019 -Accepted: October 18, 2019 -Published: October 31, 2019

\begin{abstract}
Background: Bullying is an aggressive and negative behavior of a person or a group which abuse imbalance power and it is done repeatedly. It aims to hurt the victim by mentally or physically. This action can affect social interaction of children's life. The number of bullying action showed that 50\% occurred in elementary school. Aim: This research aims to analyze the correlation between bullying behavior and social interaction ability in Tambangan Public Elementary School 02 Mijen Semarang. Methods: This study was conducted using crosssectional approach. Sample size was 122 students, selected using proportional random sampling. The data were collected using questionnaire, then analyzed using Spearman rank test. Results: The results showed that bullying case in elementary school showed in the medium level with the percentage of $54.1 \%$ (66 students), medium social interaction with the percentage of $63.1 \%$ ( 77 students). The p-value was 0,000 ; with the rho of -0.407. Conclusion: There was a correlation between bullying behavior and the social interaction ability of school-age children in Tambangan Public Elementary School 02 Mijen Semarang. Suggestion: Giving stimulus to the school-age children by using assertive communication is expected to prevent bullying action around them. Keywords: bullying; social interaction; school-age children
\end{abstract}

\section{INTRODUCTION}

Bullying is an aggressive action used to hurt someone which is done repeatedly. Data from United Nation International Children's Emergency Fund (UNICEF) in 2016 mentioned that Indonesia has the highest rank (84\%) children violation cases ${ }^{(1)}$. According to Indonesian Children Protection Commission (KPAI) in 2017, bullying often happens in elementary school which has $50 \%$ prevalence $^{(2)}$.

The factors of bullying behavior are caused by some problems related to the children confidence, family and school environment. Besides, bullying can cause the bad effects for example affecting their unhappiness. Generally, children are unhappy because they have depressing feeling to be in school and it can affect to their social life ${ }^{(3)}$

Arifin stated that social interaction is a something needed in social life which can affect the situation of individual with his or her environment. Children need the social interaction in order to help them for increasing their ability to achieve maximal results in their learning process and to help them in socialize with their environment ${ }^{(4)}$.

School-age children is the difficult phase of growth and development because in this phase, they do not want to hear any direction and suggestion by their parents. In addition, they more often follow their friends' instruction to get a confession ${ }^{(5)}$. Some kinds of bullying action occurred in school are physical bullying, verbal bullying, psychic bullying, and electronic bullying. In this situation, the most dominant kinds of bullying cases happened in a school are mocking, tempting, or teasing.

Verbal bullying cases can cause the dangerous action such as physical bullying which can affect children's social life. In this case, they will be difficult to have a good interaction with someone else. In the other words, good interaction ability is totally needed to be able in good socialize for their environment.

Based on the results of observation and interview which was done by the teacher and students in Tambangan Public Elementary School 02 Mijen Semarang on Febuary 18, 2019, it was found that verbal bullying actions could be identified as mocking, intimidating, bluffing, and calling someone using his/her parent's name or unique name. Physical bullying could be identified in the form of beating, pinching, pushing someone's body, stepping on someone's foot, kicking, and spitting on. Based on this case, there was a student who often being alone. In this location, bullying behavior not only happened in the break time but also it happened in the process of learning time in class. This problem gives negative effect for the introvert children since they will be difficult to interact with others. 
According to above situations, the researcher stated a problem statement as "is there correlation between bullying behavior with social interaction ability of the school-age children in Tambangan Public Elementary School 02 Mijen Semarang?" Moreover, it aims to analyze the correlation between bullying behavior with the social interaction of school-age children in Tambangan Public Elementary School 02 Mijen Semarang.

\section{METHODS}

This study was conducted using cross-sectional approach. This study was conducted in June 2019 in Tambangan Public Elementary School 02 Mijen Semarang. In this case, the population was all students in Tambangan Public Elementary School 02 Mijen Semarang with the total of 175 students and the sample size was 122 students, selected using proportional random sampling technique. The data of bullying behavior and social interaction ability of school-age children were collected using questionnaire. Spearman's rank test was used to analyze the data.

\section{RESULTS}

According to Table 1, there were Grade $2(22.1 \%)$ which had the highest rank of bullying action. In addition, the most dominant gender was male students with the percentage of $50.8 \%$.

Table 1. The distribution of grades and gender of the students in Tambangan Public Elementary School 02 Mijen Semarang

\begin{tabular}{|c|c|c|}
\hline $\begin{array}{c}\text { Characteristic of } \\
\text { respondent }\end{array}$ & Frequency & Percentage \\
\hline Grades & 20 & 16.4 \\
1 & 27 & 22.1 \\
2 & 24 & 19.7 \\
3 & 25 & 20.5 \\
4 & 26 & 21.3 \\
5 & 122 & 100 \\
Total & 62 & \\
Gender & 60 & 50.8 \\
Male & 122 & 100 \\
Female & & \\
Total & &
\end{tabular}

Table 2. Distribution of bullying behavior of students in Tambangan Public Elementary School 02 Mijen Semarang

\begin{tabular}{|c|c|c|}
\hline Bullying action & Frequency & Percentage \\
\hline High & 23 & 18.9 \\
Medium & 66 & 54.1 \\
Low & 33 & 27.0 \\
Total & 122 & 100 \\
\hline
\end{tabular}

Based on Table 2, the most bullying behavior of school-age children in Tambangan Public Elementary School 02 Mijen Semarang were medium (54.1\%).

Table 3. Distribution of social interaction ability by school-age children in Tambangan Public Elementary School 02 Mijen Semarang

\begin{tabular}{|c|c|c|}
\hline Social interaction ability & Frequency & Percentage \\
\hline High & 19 & 15.6 \\
Medium & 77 & 63.1 \\
Low & 26 & 21.3 \\
Total & 122 & 100 \\
\hline
\end{tabular}


Based on Table 3, the highest social interaction was in medium category $(63.1 \%)$.

Table 4. Correlation between the bullying behavior and social interaction of school-age children in Tambangan Public Elementary School 02 Mijen Semarang

\begin{tabular}{|c|c|c|c|c|c|c|c|c|}
\hline \multirow{2}{*}{$\begin{array}{c}\text { Bullying } \\
\text { behavior }\end{array}$} & \multicolumn{5}{|c|}{ Social Interaction Ability } & \multirow{2}{*}{ Total } & \multirow{2}{*}{ Percentage } \\
\cline { 2 - 7 } & Frequency & Percentage & Frequency & Percentage & Frequency & Percentage & & \\
\hline High & 0 & 0 & 8 & 34.8 & 15 & 65.2 & 23 & 100 \\
\hline Medium & 10 & 15.2 & 49 & 74.2 & 7 & 10.6 & 66 & 100 \\
\hline Low & 9 & 27.3 & 20 & 60.6 & 4 & 12.1 & 33 & 100 \\
\hline Total & 19 & 15.6 & 77 & 63.1 & 26 & 21.3 & 122 & 100 \\
\hline \multicolumn{7}{|c|}{ p-value $=0.000 ;$ correlation coefficient $=-0.407$} &
\end{tabular}

According to the result of Spearman's rank test, the p-value was 0.000; while the correlation coefficient was -0.407 (there was the significant correlation between the bullying behavior and social interaction of school-age children in Tambangan Public Elementary School 02 Mijen Semarang.

\section{DISCUSSION}

According to the results of this study, it was found that the most dominant respondent was from second grades with the total 27 students, meanwhile the least respondent was from the first grade with the total 20 students. Generally, physical activities often happened in the school-age children and it could increase their motor ability. In this situation, the higher activities, the higher motor skill will children have. Besides, it will also increase physical bullying cases. ${ }^{(6)}$ According to Ismiatun's research (2014), it was proved that bullying could happen from the first till fifth grades students. In every grade, bullying behavior had different cases even it happened every day in Gondolayu Public Elementary School Yogyakarta. ${ }^{(7)}$

The results indicated that male respondents were 62 students meanwhile female respondents were 60 students. Priyatna (2010) mentioned that physical bullying behavior was often found in male students rather than female. Male students tend to have aggressiveness and power. So, they wanted to be stronger to lead his friends. ${ }^{(8)}$ In elementary school, children usually have some characters such as obey the rules, tend to praise themselves, like playing, compare with the others, grouping, have high curiosity, and be the leader to their friends. ${ }^{(9)}$

Based on the observation, the researcher found that some of the respondents did physical bullying action when they were taking a pen for someone else to fill a piece of questionnaire from the researcher. In here, a student pushed his friend down to take that pen. So, the researcher rebuked and gave suggestion to warn him.

The result of descriptive analysis of bullying action could be seen that the high number bullying action was 23 students, medium number bullying action was 66 students, and low number bullying action was 33 students. It could be concluded that the most bullying behavior happened in Tambangan Public Elementary School 02 Mijen Semarang was medium level. Meanwhile, according to Andriani's research (2017) stated that bullying behavior in Sidomulyo Public Elementary School 04 Ungaran was low with the number 29 students and none bullying action was 62 students. ${ }^{(10)}$

Physical bullying could be found in the case that student pushed and hit his/her friend. Moreover, nonphysical bullying was found in the kinds of verbal bullying such as mocking, calling with the unique name, and scolding his/her friend. The kinds of non-verbal bullying happened in Tambangan Public Elementary School 02 Mijen Semarang which involved be quiet with the victim, stay away, and look someone cynically. In this case, it could give the great effect for the victim because it appeared discomfort feeling, afraid, inferiority, bad social adaptation. He or she was afraid going to school. Besides, it would cause children to be introvert, low academic performance and concentration. ${ }^{(11)}$

According to Mulachela's (2017), high category of bullying behavior occurred if someone has low and negative self-esteem. So, he or she will has negative characters, worst physical condition, and high criminality risk. High bullying behavior was categorized if the children do verbal, physical, psychic and electronic/cyber. Those cases can cause gap relationship and there will be injustice relationship with the others. ${ }^{(12)}$

Descriptive analysis about social interaction could be seen through the percentage of social interaction ability with high category 19 students, medium category was 77 students, and low category was 26 students. Based on the data, most of the students in Tambangan Public Elementary School 02 Mijen Semarang had medium social category of interaction ability. 
Hurlock (2011) stated that a person with the high social interaction ability is a person who can balance his or her attitude with the rules or guidance in the environment. However, not all individual is able to have a good social interaction. High and low levels of individual interaction are totally affected by family and social life around them. ${ }^{(13)}$

The distinction of students' condition such as the level of intelligence, economic condition, and popularity can make their friend relationship is not good. Based on the data observation, the researcher found that there was an introvert student who was far with the other since he had different character with his friends.

Spearman rank test indicated that there was a significance correlation between bullying behavior with social interaction ability. Meanwhile, Putri's research in 2016 stated that there was a correlation between bullying behavior with social interaction ability in the third grades students in Minomartani Public Elementary School 6 Sleman with p-value of 0.000 and the correlation coefficient of -0.832. It means that there was strong correlation and opposite direction. ${ }^{(14)}$

\section{CONCLUSION}

Based on the results of the study it can be concluded that the social interaction ability of students in in Tambangan Public Elementary School 02 Mijen Semarang, is related to bullying behavior.

\section{REFERENCES}

1. Sindo. Indonesia Occupies the Highest Position of Harassment in ASEAN (Indonesia Tepati Posisi Tertinggi Perundungan di ASEAN) [Internet]. 2016 [cited 2019 Apr 4]. Available from: https://nasional.sindonews.com/read/1223442/15/UNICEFindonesia-tempati-posisi-tertinggi-perundungandi-asean-1500880739

2. Novianto RD. KPAI Notes in Education: The Most Bullying Cases (Catatan KPAI Bidang Pendidikan: Kasus Bullying Paling Banyak) [Internet]. Available from: https://nasional.sindonews.com/read/1324346/15/catatan-kpai-bidang-pendidikan kasus-bullying-palingbanyak-1532346331

3. Wharton S. How to Stop That Bully/Menghentikan si Tukang Teror. Yogyakarta: KANISIUS; 2009.

4. Arifin BS. Social Psychology (Psikologi Sosial). Bandung: CV Pustaka Setia; 2015.

5. Soetjiningsih, Christiana H. Child development from conception to late childhood (Perkembangan Anak sejak Pembuahan sampai dengan Kanak-Kanak Akhir). Jakarta: Prenada Medika Group; 2014.

6. Wulandari D. Children's Nursing Textbooks (Buku Ajar Keperawatan Anak). Yogyakarta: Pustaka Pelajar; 2016.

7. Ismiatun R. Bullying at Gondolayu Elementary School, Yogyakarta City (Bullying di SD Negeri Gondolayu Kota Yogyakarta) [Internet]. UNY. 2014 [cited 2019 Jul 11]. Available from: http://eprints.uny.ac.id; 2014 (accesed 11 juli 2019).

8. Priyatna A. Let's End Bullying: Understanding, Preventing, and Overcoming Bullying (Memahami, Mencegah, dan Mengatasi Bullying). Jakarta: PT. Elex Media Komputindo; 2010.

9. Yusuf S. Child and Adolescent Developmental Psychology (Psikologi Perkembangan Anak dan Remaja). Bandung: PT. Remaja Rosdakarya; 2017.

10. Andriani NS. Relationship between Bullying Behavior and Social Interaction Capabilities of Students Aged 10-12 Years at SDN 04 Sidomulyo Ungaran (Hubungan Perilaku Bullying dengan Kemampuan Interaksi Sosial Siswa Usia 10-12 Tahun di SDN 04 Sidomulyo Ungaran) [Internet]. 2017 [cited 2019 Apr 10]. Available from: https://studylibid.com/doc/1047446/hubungan-perilaku-bullying-dengan-kemampuan

11. Wiyani NA. Save Our Children from School Bullying. Yogyakarta: AR-RUZZ Media; 2012.

12. Mulachela ZH. Bullying Behavior in Adolescents In terms of self esteem and Gender (Perilaku Bullying pada Remaja Ditinjau dari self esteem dan Jenis Kelamin) [Internet]. UMS. 2017 [cited 2019 Jul 27]. Available from: http://eprints.ums.ac.id/50120/2/Naskah\%20Publikasi.pdf

13. Hurlock EB. Developmental Psychology: An Approach Throughout Vulnerable Life (Psikologi Perkembangan: Suatu Pendekatan Sepanjang Rentan Kehidupan). Jakarta : Erlangga; 2011.

14. Putri RP. Relationship between Bullying Behavior and Social Interaction Capabilities of Class III Students of SDN Minomartani 6 Sleman (Hubungan Perilaku Bullying dengan Kemampuan Interaksi Sosial Siswa Kelas III SDN Minomartani 6 Sleman. Jurnal Pendidikan Guru Sekolah Dasar). 2016;2(5). Available from: http://journal.student.uny.ac.id/ojs/index.php/pgsd/article/download/415/672 